\title{
Faecal calprotectin concentrations in apparently healthy children aged 0-12 years in urban Kampala, Uganda: a community-based survey
}

\author{
Elin Hestvik ${ }^{1,2^{*}}$, James K Tumwine ${ }^{3}$, Thorkild Tylleskar ${ }^{1}$, Lena Grahnquist ${ }^{4}$, Grace Ndeezi ${ }^{1,3}$,
} Deogratias H Kaddu-Mulindwa ${ }^{5}$, Lage Aksnes ${ }^{2,6}$, Edda Olafsdottir ${ }^{2}$

\begin{abstract}
Background: Calprotectin is a calcium and zinc binding protein, abundant in neutrophils and is extremely stable in faeces. Faecal calprotectin is used as a non-specific marker for gastrointestinal inflammation. It has a good diagnostic precision to distinguish between irritable bowel syndrome and inflammatory bowel disease. Studies have established normal concentrations in healthy children; all these studies have been performed in high-income countries. The objective of this study was to determine the concentration of faecal calprotectin in apparently healthy children aged 0-12 years in urban Kampala, Uganda.
\end{abstract}

Method: We tested 302 apparently healthy children aged, age 0-12 years (162 female, 140 male) in urban Kampala, Uganda. The children were recruited consecutively by door-to-door visits. Faecal calprotectin was analyzed using a quantitative enzyme-linked immunosorbent assay. Faeces were also tested for Helicobacter pylori (H. pylori) antigen, for growth of enteropathogens and microscopy was performed to assess protozoa and helminths. A short standardized interview with socio-demographic information and medical history was obtained to assess health status of the children.

Results: In the different age groups the median faecal calprotectin concentrations were $249 \mathrm{mg} / \mathrm{kg}$ in $0<1$ year $(\mathrm{n}=54), 75 \mathrm{mg} / \mathrm{kg}$ in $1<4$ years $(\mathrm{n}=89)$ and $28 \mathrm{mg} / \mathrm{kg}$ in $4<12$ years $(\mathrm{n}=159)$. There was no significant difference in faecal calprotectin concentrations and education of female caretaker, wealth index, gender, habits of using mosquito nets, being colonized with $\mathrm{H}$. pylori or having other pathogens in the stool.

Conclusion: Concentrations of faecal calprotectin among healthy children, living in urban Ugandan, a low-income country, are comparable to those in healthy children living in high-income countries. In children older than 4 years, the faecal calprotectin concentration is low. In healthy infants faecal calprotectin is high. The suggested cut-off concentrations in the literature can be used in apparently healthy Ugandan children. This finding also shows that healthy children living under poor circumstances do not have a constant inflammation in the gut. We see an opportunity to use this relatively inexpensive test for further understanding and investigations of gut inflammation in children living in low-income countries.

\section{Background}

Calprotectin is a calcium and zinc binding heterocomplex protein, described by Fagerhol et al. in 1979 [1]. It is abundantly present in the cytosol fraction of neutrophils [2], it is also found in monocytes/macrophages,

\footnotetext{
* Correspondence: elin.hestvik@cih.uib.no

'Centre for International Health, University of Bergen, Årstadveien 21, N-5009 Bergen, Norway

Full list of author information is available at the end of the article
}

but is absent from platelets and lymphocytes [3]. It is used as a non-specific marker for activation of granulocytes and mononuclear phagocytes. Calprotectin is remarkably resistant to degradation in the presence of calcium, it is stable in faeces stored for 7 days at room temperature [4] and no changes over time have been found by storing the faeces at $-20^{\circ} \mathrm{C}$ [5]. A faecal calprotectin Enzyme-linked immunosorbent assay (ELISA) test has been available since 1994 [6].

\section{() Biomed Central}


Faecal calprotectin is used as a non-specific marker for gastrointestinal (GI) inflammation. It has been shown to correlate significantly with four day faecal excretion of ${ }^{111}$ indium [7], the gold standard for intestinal inflammation. Faecal calprotectin concentrations are elevated both in adults [4,8] and children [9-11] with inflammatory bowel disease (IBD) and can be used to evaluate the degree of inflammation in these patients. For the diagnosis and more thorough investigation of IBD, colonoscopy is needed. There is a significant correlation between calprotectin concentration in gut lavage fluid and intestinal permeability, suggesting that increased intestinal permeability in IBD might be a consequence of inflammation in the intestinal wall and hereby increased transepithelial migration of neutrophils [12]. Faecal calprotectin may differentiate between irritable bowel disease and IBD in school-age children [13]. Faecal calprotectin is found elevated in adults and children with various GI infections [14-16], but the concentrations are lower than in persons with IBD. Calprotectin is present in plasma, and the faecal calprotectin concentrations might be increased with any bleeding into the GI tract [17]. Elevated concentrations of faecal calprotectin have been described in cystic fibrosis, rheumatoid arthritis, Crohn's disease, ulcerative colitis and bacterial infection [6], as well as neoplastic conditions [17] and Non-Steroidal Anti-Inflammatory Drugs (NSAID) induced enteropathy [18]. In young infants high faecal calprotectin concentrations are normal $[10,19]$. In healthy pre-term babies the concentrations are comparable with healthy term-babies [20,21], but in very low birth weight babies (VLBW) developing severe abdominal disease for instance necrotizing enterocolitis (NEC), faecal calprotectin concentrations tend to increase even more and it may be a marker for early diagnosis [20,21].

Normal values for faecal calprotectin in different age groups have been investigated in high-income countries [10,20-22]. To our knowledge, there are no published articles on faecal calprotectin concentrations in apparently healthy children living in low-income countries. In order to even discuss the importance of calprotectin in lowincome countries, a baseline of healthy children has to be done. A study on faecal calprotectin in Schistosomiasis infected Ugandan children and adults have not shown an increase of faecal calprotectin in the infected persons [23].

The objective of this study was to determine the concentration of faecal calprotectin in apparently healthy children aged 0-12 years in urban Kampala, Uganda.

\section{Methods}

\section{Study design, site and population}

This is a cross-sectional survey in apparently healthy children aged 0-12 years in urban Kampala, Uganda.
A detailed description is provided elsewhere [24]. Of the 472 children approached, 31 declined participation (6.6\%). Forty potential participants $(9.1 \%)$ were excluded from the final analysis due to positive human immunodeficiency virus (HIV) test (5), incomplete data (1), failed to produce stool within two weeks (5) and medical conditions (29), figure 1 . Within the group excluded due to medical condition 23 reported to have ongoing diarrhoea or diarrhoea within last two weeks, two had congenital heart disease, one had a rectal prolapse, two reported to have had nose bleeding within last two weeks and one reported to have peptic ulcer. The youngest child encountered in the survey was one week. An additionally 99 stool samples were lost during transport to the final laboratory. Children reporting chronic cough/asthma were included as no studies have not shown significant elevated concentrations of faecal calprotectin in children with asthma [25].

\section{Data collection}

The data collection took place October-November 2007 in Kampala, Uganda. All stool samples were investigated by microscopy for protozoa and helminths, a culture was performed to assess for enteropathogens and all samples were tested for Helicobacter pylori (H. pylori) with a rapid faecal monoclonal antigen test [24]. In order to assess the faecal calprotectin concentrations among healthy, non-HIV-infected, children in this high

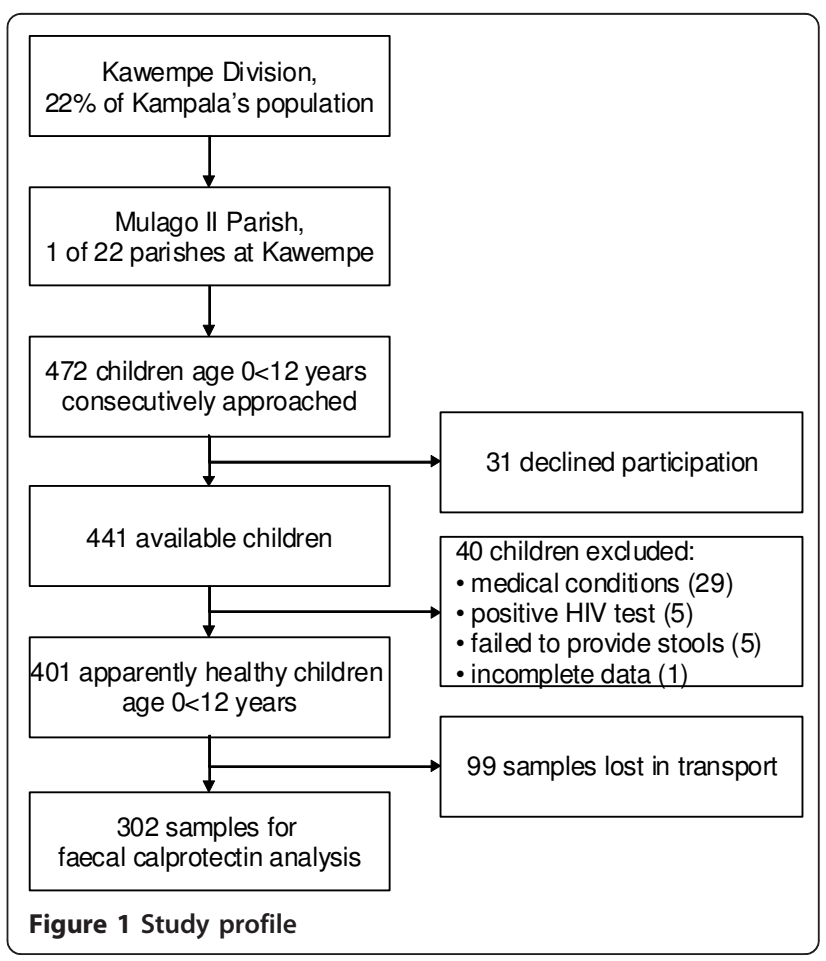


endemic area, all participants and their caretakers were offered a voluntary HIV test.

\section{Stool sampling and CALPRO ${ }^{\circledR}$ Calprotectin ELISA Test}

A stool sample was requested from each participating child. All participants were instructed from the data collectors to pass stool on a newspaper that was handed out and thereafter the stool was collected with the spoon following the air tight containers either at time of the encounter, at the end of the day, or the following morning. All participants who had not delivered a stool sample were visited once daily for the next two weeks. A participant was included in the survey if he/she produced a stool sample within two weeks after the initial interview. Stool samples were transported at ambient temperature from the field to the laboratory twice daily and stored in $\mathrm{a}+4^{\circ} \mathrm{C}$ fridge until the same afternoon or the following day when a stool portion was frozen in a clean Eppendorf tube at $-80^{\circ} \mathrm{C}$. The frozen stool samples were transported on ice by air to Bergen where the final analyses were performed in July 2009 using CALPRO ${ }^{\circledR}$ Calprotectin ELISA Test (ALP). Instructions given by the manufacturer were followed (http://www.calpro.no). Eighty two of 302 faecal calprotectin samples (27\%) were measured twice to evaluate the consistency within the pairs. In order to manage the data, all 164 concentrations were ranged into quartiles. The strength of agreement, kappa $(95 \% \mathrm{CI})$, was very good, $0.81(0.70$ 0.92). The CALPRO ${ }^{\circledR}$ Calprotectin ELISA Test (ALP) is a quantitative method for the determination of calprotectin in faeces. Calprotectin was expressed as milligram per kilogram $(\mathrm{mg} / \mathrm{kg})$ of faeces. For children younger than 4 years of age there are no reference limits established for a positive test.

\section{Statistical analysis}

The statistical analysis were performed as described elsewhere [24]. The data were exported to SPSS version 17.0 for statistical analysis. The concentration of faecal calprotectin was expected to have a skewed distribution, therefore the median was used. The confidence interval (CI) reported was set to $95 \%$. All tests were 2-sided, p-value of 0.05 or less was considered significant. Faecal calprotectin values in the different groups were compared by using Mann-Whithey $U$ test (for to different groups) and by Kruskal-Wallis $\mathrm{H}$ test (for three or more groups). Age was reported in mean and years.

\section{Ethics}

Ethical approval was obtained from Makerere University, Faculty of Medicine, Research and Ethics Committee in Uganda and the Regional Committee for Medical and Health Research Ethics, West-Norway (REK-VEST) in Norway. The data collectors were trained in ethical issues prior to the study. Oral and written information about the study was given to the caretakers either in English or the local language. Informed consent was obtained from all the caretaker of the participants in the study.

\section{Results}

The mean age $( \pm \mathrm{SD})$ of all the participants was 4.9 (3.6) years, for girls 5.4 (3.7) years and boys 4.4 (3.5) years. For the children above 4 years the mean age $( \pm \mathrm{SD})$ was 7.9 (2.2), for girls 8.0 (2.3) and boys 7.8 (2.2). Gender was unequally represented in the study, 1) for all participants 162 (53.6\%) girls and 140 (46.4\%) boys, 2) for the children above 4 years $96(60.4 \%)$ girls and $63(39.6 \%)$ boys.

The faecal calprotectin concentration had a skewed distribution in the 302 apparently healthy children, figure 2. In the three age groups the number of children were $54(0<1$ year $), 89(1<4$ years $)$ and $159(4<12$ years). The median faecal calprotectin concentrations with $95 \%$ CI were $249 \mathrm{mg} / \mathrm{kg}(180-403)(0<1$ year $)$, $75 \mathrm{mg} / \mathrm{kg}(53-119)(1<4$ years $)$ and $28 \mathrm{mg} / \mathrm{kg}(25-35)$ $(4<12$ years), table 1 . There was a significant difference in the faecal calprotectin concentrations across all three age groups, regardless of gender. In the younger age group the concentration of faecal calprotectin was more spread and had a lager range than in the older children, where the values were skewed towards the lower end of the scale, figure 2. By dividing the children younger than 1 year into 3 groups, $0<3$ months $(\mathrm{n}=14), 3<6$ months $(\mathrm{n}=13)$ and $6<12$ months $(\mathrm{n}=27)$ we found that the youngest children had a trend for highest concentrations of faecal calprotectin (with $95 \% \mathrm{CI}$ ); 354 (195-621) $(0<3$ months), 278 (85-988) ( $3<6$ months) and 183 (109-418) $(6<12$ months), but none of this differences were statistically different, table 1 .

We performed a subgroup analysis of children aged $4<12$ years where faecal calprotectin has proven to be most useful and where reference values are available. By performing Mann-Whithey U and Kruskal-Wallis H test there was no significant relation between concentration of faecal calprotectin and education of the female caretaker, wealth index, sex, child using a mosquito net regularly, being colonized by H. pylori, Giardia intestinalis (G.intestinalis) or other pathogens, table 2. Within the last three months before inclusion $28.6 \%$ of the children had been treated with antibiotics and $24.2 \%$ had been treated for malaria; there were no significant difference in median faecal calprotectin value in the treated versus the not treated participants.

Of the 159 children above 4 years, 131 (82.4\%) had faecal calprotectin below $100 \mathrm{mg} / \mathrm{kg}$, and 143 of the 159 children (89.9\%) older than 4 years, had faecal calprotectin below $150 \mathrm{mg} / \mathrm{kg}$, table 3 . Of the 28 children having a faecal calprotectin higher than $100 \mathrm{mg} / \mathrm{kg}, 11 \mathrm{had}$ an intestinal infection with $G$. intestinalis and 1 had 


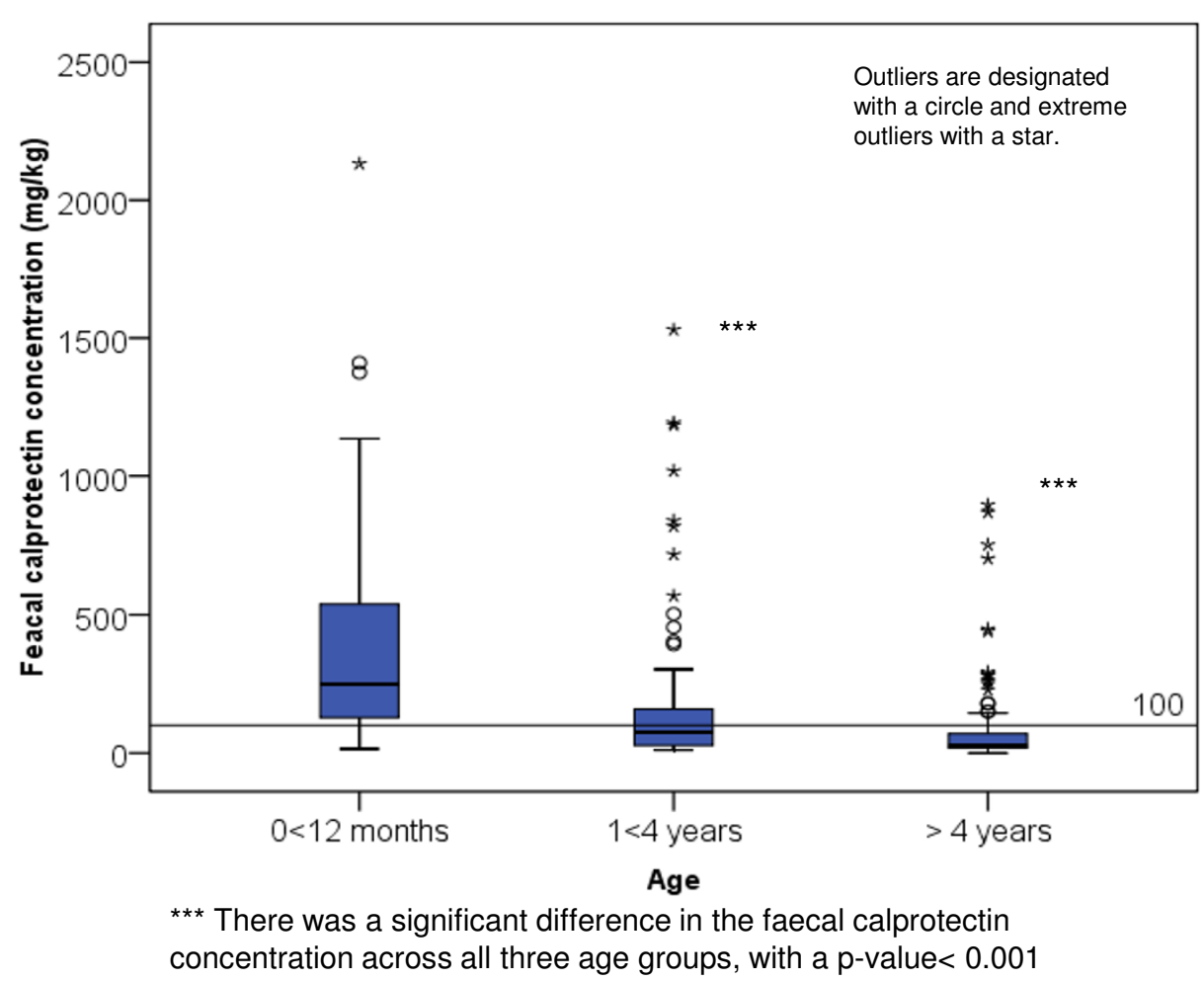

Figure 2 Median faecal calprotectin with $95 \% \mathrm{Cl}$ by age in years

Ancylostoma duodenale. However, in 16 children we did not find any explanation for faecal calprotectin over $100 \mathrm{mg} / \mathrm{kg}$, the mean faecal calprotectin was $295 \mathrm{mg} / \mathrm{kg}$ with a maximum of $895 \mathrm{mg} / \mathrm{kg}$. Thirteen of the sixteen were female, had a mean age $( \pm \mathrm{SD})$ of 7.8 (2.3) years, only three of them were using a mosquito bed net regularly and ten were colonized with $H$. pylori.

Six participants reported themselves to be chronically ill, five with chronic cough/asthma and one with headache, all of them had a faecal calprotectin less than $40 \mathrm{mg} / \mathrm{kg}$. In one culture only an enteric pathogen was

Table 1 Faecal calprotectin concentration in apparently healthy children by age

\begin{tabular}{lcc}
\hline Age & Number (\%) & Median FC ( $\mathbf{m g} / \mathbf{k g}) \mathbf{( 9 5 \% C l )}$ \\
\hline $0<3$ months & $14(4.6)$ & $345(195-621)$ \\
$3<6$ months & $13(4.3)$ & $278(85-988)$ \\
$6<12$ months & $27(8.9)$ & $183(109-418)$ \\
$1<4$ years & $89(29.5)$ & $75(53-119)^{*}$ \\
$4<12$ years & $159(52.6)$ & $28(25-35) *$ \\
\hline All & $302(100)$ & $52(40-73)$
\end{tabular}

* Difference in median, $p$-value $<0.001$ if compared with the whole group of children younger than 12 months.

$\mathrm{Cl}$ confidence interval

FC faecal calprotectin isolated; Campylobacter spp. The child was 10 years old and the faecal calprotectin was $43 \mathrm{mg} / \mathrm{kg}$.

The mean age $( \pm \mathrm{SD})$ in the children whom stool was lost in transport was 4.5 (3.7) years, with more boys $(58.6 \%)$ than girls $(41.4 \%)$. Colonization rate with H. pylori was $36.4 \%$. The education of the female caretaker, the practice of using mosquito net and the wealth index were similar to the once completed the survey.

\section{Discussion}

This is the first survey of faecal calprotectin concentrations in an apparently healthy population in SubSaharan Africa. We have shown that cut-off values recommended to use in children in high-income countries living in a relatively "clean environment" also are valid in children in a low-income country. In our study the median faecal calprotectin in apparently healthy children older than 4 years was $28 \mathrm{mg} / \mathrm{kg}$ and within the suggested cut-off concentrations for the test used. By comparing our findings to other studies looking at apparently healthy children, our median with $95 \%$ CI is comparable to those studies $[9,10,16,22,26,27]$.

Since none of the children with elevated faecal calprotectin concentrations were followed up to see if the concentrations normalized over time, we do not have an explanation for faecal calprotectin higher than $100 \mathrm{mg} / \mathrm{kg}$ 
Table 2 Faecal Calprotectin concentration in 159 apparently healthy children age $4<12$ years

\begin{tabular}{|c|c|c|c|}
\hline & Number $\mathrm{N}(\%)$ & Median FC concentration $(\mathrm{mg} / \mathrm{kg})(95 \% \mathrm{Cl})$ & p-value \\
\hline \multicolumn{4}{|l|}{ Sex } \\
\hline Female & $96(60.4)$ & $27.5(22-37)$ & 0.94 \\
\hline Male & 65 (39.6) & $29(24-38)$ & \\
\hline \multicolumn{4}{|l|}{ Education of female caretaker } \\
\hline Not completed secondary school & $131(82.4)$ & $28(24-35)$ & 0.74 \\
\hline Completed secondary & $28(17.6)$ & $28(20-63)$ & \\
\hline \multicolumn{4}{|l|}{ Using a mosquito net } \\
\hline Yes & $52(32.7)$ & $28(21-35)$ & 0.36 \\
\hline No & $107(67.3)$ & $29(24-40)$ & \\
\hline \multicolumn{4}{|l|}{ Wealth index } \\
\hline Poor & $51(32.1)$ & $25(20-34)$ & 0.39 \\
\hline Poorer & $55(34.6)$ & $30(24-46)$ & \\
\hline Poorest & $53(33.3)$ & $29(22-40)$ & \\
\hline \multicolumn{4}{|l|}{ G.intestinalis seen by microscopy } \\
\hline Yes & $35(22.0)$ & $40(23-34)$ & 0.12 \\
\hline No & $124(78.0)$ & $27.5(24-88)$ & \\
\hline \multicolumn{4}{|l|}{ H. pylori colonization } \\
\hline Yes & $78(49.1)$ & $33(25-46)$ & 0.12 \\
\hline No & $81(50.9)$ & $26(22-34)$ & \\
\hline \multicolumn{4}{|c|}{ Other pathogens seen by microscopy a } \\
\hline Yes & $13(8.2)$ & $34(18-46)$ & 0.66 \\
\hline No & $146(91.8)$ & $28(23-35)$ & \\
\hline
\end{tabular}

a Campylobacter jejuni (1), Hymenolepis nana (5), Entamoeba histolytica (2), Ancylostoma duodenale (3), Ascaris lumbricoides (2)

$\mathrm{N}$ number

$\mathrm{Cl}$ confidence interval

FC faecal calprotectin

in 16 children. Spontaneous normalization in faecal calprotectin concentration without disease has been described [22]. Use of NSAID is one common explanation we did not control for [18]. The participants did not go through a clinical examination and anal fissures with bleeding or colon polyps as described in other studies [28], could contribute to the increased concentration of faecal calprotectin. We excluded all children reporting diarrhoea within last two weeks before encountered in the survey, but some few children could be carrier of asymptomatic intestinal infection from pathogens we have not examined for, for instance Cryptosporidia, Some children with protozoa or helminths might have

Table 3 Distribution of the faecal calprotectin in apparently healthy children $>\mathbf{4}$ years

\begin{tabular}{lccc}
\hline $\begin{array}{l}\text { Faecal calprotectin } \\
\text { concentration }(\mathbf{m g} / \mathbf{k g})\end{array}$ & $\begin{array}{c}\text { Number } \\
\mathbf{N}\end{array}$ & $\begin{array}{c}\text { Percent } \\
\%\end{array}$ & $\begin{array}{c}\text { Cumulative } \\
\text { percent } \%\end{array}$ \\
\hline$<50$ & 111 & 69.8 & 69.8 \\
$50<100$ & 20 & 12.6 & 82.4 \\
$100<150$ & 12 & 7.5 & 89.9 \\
$\geq 150$ & 16 & 10.1 & 100.0 \\
\hline Total & 159 & 100.0 & 100.0 \\
\hline
\end{tabular}

N Number been missed due to single sample investigation and without additional tests. Ideally, identification of protozoa and helminths are done using 3 consecutive stool samples $[29,30]$. A strength of our survey is that our children were clinically healthy without diarrhoea and were HIV negative. Another strength is that only one stool culture was positive. Our study was preformed with the improved faecal calprotectin assay, and it has been argued that it gives a better separation between normal and pathologic values [5]. We also adjusted for age within the group of children age $4<12$ years by applying bivariable linear regression (not shown), but we did not find any changes.

There are few studies on faecal calprotectin and GI-infections [15]. Colonization with G. intestinalis and $H$. pylori are common in children living in Sub-Saharan Africa $[24,31,32]$. In this survey we have found comparable colonization rates. Despite this the median faecal calprotectin was within the recommended cut-off; $37.5 \mathrm{mg} / \mathrm{kg}$ for G. intestinalis and $33 \mathrm{mg} / \mathrm{kg}$ for H. pylori. The findings in the G. intestinalis infected group were comparable to a Norwegian study in adults with chronic abdominal pain after G. intestinalis infection [14], where they found a median faecal calprotectin concentration of $28 \mathrm{mg} / \mathrm{kg}$ in the G. intestinalis positive 
patients. Colonization with $H$. pylori can cause changes in the gastric mucosa [33], but there are no reports of increased inflammation in the lower GI tract. Upper-GI disorders have showed little increase in faecal calprotectin levels [34]. Tibble et al. 2002 [35] found faecal calprotectin above the cut-off limit in participants infected by G. intestinalis in their study, but those were symptomatic with diarrhoea.

Low-and middle-income countries are reporting an increase in the incidence of IBD since the 1990'ties [36]. To the best of our knowledge there are no studies on the prevalence of IBD in black children living in Sub-Saharan Africa. In addition children living in low-income countries have a higher burden of GI diseases including the effect of HIV on the GI tract. This brings up the need for good methods for improved diagnostics and awareness of GI disorders. This study shows that apparently healthy children do not have an ongoing inflammatory process in the GI tract, and that methods used in high-income countries with a lower burden of GI infection disease also are valid in low-and middle-income countries. There is an ongoing discussion on which upper limit, $100 \mathrm{mg} / \mathrm{kg}$ versus $50 \mathrm{mg} /$ $\mathrm{kg}$, provides the best accuracy in diagnosing IBD [37]. For the test we used, an upper limit of $50 \mathrm{mg} / \mathrm{kg}$ has been suggested $[5,38]$. Tibble et al. 2000 used a cut-off concentration of $30 \mathrm{mg} / \mathrm{l}$ [7], which is equal to $150 \mathrm{mg} / \mathrm{kg}$ [5]. If we use a cut-off of $100 \mathrm{mg} / \mathrm{kg}, 82.4 \%$ of the children had concentrations below, if we use $150 \mathrm{mg} / \mathrm{kg}, 89.9 \%$ of the children had faecal calprotectin concentrations within that range, table 3 . A recently published meta-analysis concludes that faecal calprotectin gives a diagnostic precision in distinguishing IBD from non-IBD diagnosis, with higher precision at a cut-off of $100 \mathrm{mg} / \mathrm{kg}$ versus $50 \mathrm{mg} / \mathrm{kg}$ [37].

Fagerberg et al [22] have documented that the same cut-off limits used in adults are also applicable in children older than 4 years. In infants and toddlers there are no recommended cut-off values. In our study they had higher faecal calprotectin concentrations than children older than 4 years. The concentrations were comparable to those found in other studies of apparently healthy children $[10,27]$. Our findings contribute to establish reference values also for children younger than 4 years of age. We did not look at feeding practice in children younger than 1 year. Studies diverge in the conclusions if faecal calprotectin is higher in exclusively breast feed children than in mix feed children $[39,40]$.

There were no differences in median faecal calprotectin according to sex $[9,10,16]$, wealth index, health behaviour or education level of female caretaker. This is to our knowledge demonstrated for the first time.

\section{Conclusion}

Apparently healthy Ugandan children, age $4<12$ years, have comparable concentrations of faecal calprotectin to similar aged children in high-income countries. The concentration of faecal calprotectin is high in Ugandan children under 1 year of age, and is raised in toddlers. Faecal calprotectin can be used in combination with extended history and stool microscopy as a diagnostic tool in children in need for further investigation for prolonged diarrhoea in a limited recourse setting. Faecal calprotectin concentrations over $100 \mathrm{mg} / \mathrm{kg}$ in children warrant follow-up. We see an opportunity to use this relatively inexpensive test for further understanding and investigations of gut inflammation in children living in low-income countries.

\section{Acknowledgements}

We would like to thank all the children, their caretakers, the data collectors and the laboratory technicians who participated in the study. The study was conducted as a part of the collaboration between Department of Paediatrics and Child Health, Makerere University and Centre for international health, University of Bergen. The study was funded by the University of Bergen and the GlobVac programme by the Research Council of Norway, grant no 172226 Focus on Nutrition and Child Health: Intervention Studies in Lowincome Countries.

\section{Author details}

${ }^{1}$ Centre for International Health, University of Bergen, Årstadveien 21, N-5009 Bergen, Norway. ${ }^{2}$ Department of Paediatrics, Haukeland University Hospital, N-5021 Bergen, Norway. ${ }^{3}$ Department of Paediatrics and Child Health, Makerere University College of Health Sciences, School of Medicine, P.O Box 7072, Kampala, Uganda. “Department of Women's and Children's Health, Karolinska Institutet, 17176 Stockholm, Sweden. ${ }^{5}$ Department of Microbiology, Makerere University College of Health Sciences, School of Medicine, School of Biomedical Sciences, P.O Box 7072, Kampala, Uganda. 'Department of Clinical Medicine, University of Bergen, Bergen, Norway.

\section{Authors' contributions}

EH participated in the conception, design and implementation of the study, statistical analysis, interpretation and writing the manuscript. JKT participated in conception, design and implementation of the study. TT participated in the conception and design of the study, statistical analysis, interpretation and writing the manuscript. LG participated in design of the study, interpretation and writing the manuscript. GN participated in design and implementation of the study. DKM participated in implementation of the study and preparation of the stool for calprotectin analysis. LA participated in performing the faecal calprotectin analysis, statistical analysis,

interpretation and writing the manuscript. EO participated in the conception and design of the study, statistical analysis, interpretation and writing the manuscript. All authors read and approved the final manuscript.

\section{Competing interests}

The authors declare that they have no competing interests.

Received: 25 June 2010 Accepted: 2 February 201

Published: 2 February 2011

\section{References}

1. Fagerhol MK, Dale I, Andersson T: Release and quantitation of a leucocyte derived protein (L1). Scan J Haematol 1980, 24(1980):393-398.

2. Dale I, Brandtzaeg P, Fagerhol MK, Scott H: Distribution of a new myelomonocytic antigen (L1) in human peripheral blood leukocytes. Immunofluorescence and immunoperoxidase staining features in comparison with lysozyme and lactoferrin. Am J Clin Pathol 1985, 84(1):24-34

3. Zwadlo G, Bruggen J, Gerhards G, Schlegel R, Sorg C: Two calcium-binding proteins associated with specific stages of myeloid cell differentiation are expressed by subsets of macrophages in inflammatory tissues. Clin Exp Immunol 1988, 72(3):510-515. 
4. Roseth AG, Fagerhol MK, Aadland E, Schjonsby H: Assessment of the neutrophil dominating protein calprotectin in feces. A methodologic study. Scand J Gastroenterol 1992, 27(9):793-798

5. Ton H, Brandsnes, Dale S, Holtlund J, Skuibina E, Schjonsby H, Johne B: Improved assay for fecal calprotectin. Clin Chim Acta 2000, 292(1-2):41-54.

6. Johne B, Fagerhol MK, Lyberg T, Prydz H, Brandtzaeg P, Naess-Andresen CF, Dale I: Functional and clinical aspects of the myelomonocyte protein calprotectin. Mol Pathol 1997, 50(3):113-123.

7. Tibble J, Teahon K, Thjodleifsson B, Roseth A, Sigthorsson G, Bridger S, Foster R, Sherwood R, Fagerhol M, Bjarnason I: A simple method for assessing intestinal inflammation in Crohn's disease. Gut 2000, 47(4):506-513.

8. Roseth AG, Aadland E, Jahnsen J, Raknerud N: Assessment of disease activity in ulcerative colitis by faecal calprotectin, a novel granulocyte marker protein. Digestion 1997, 58(2):176-180.

9. Bunn SK, Bisset WM, Main MJ, Golden BE: Fecal calprotectin as a measure of disease activity in childhood inflammatory bowel disease. $J$ Pediatr Gastroenterol Nutr 2001, 32(2):171-177.

10. Olafsdottir $E$, Aksnes $L$, Fluge $G$, Berstad A: Faecal calprotectin levels in infants with infantile colic, healthy infants, children with inflammatory bowel disease, children with recurrent abdominal pain and healthy children. Acta Paediatr 2002, 91(1):45-50.

11. Bunn S, Bisset M, Main M, Golden B: Faecal calprotectin as a marker of gastrointestinal inflammation during the first year of life (abstract). J Pediatr Gastroenterol Nutr 2000, 31(Suppl 2):43.

12. Berstad A, Arslan G, Folvik G: Relationship between intestinal permeability and calprotectin concentration in gut lavage fluid. Scand J Gastroenterol 2000, 35(1):64-69.

13. Schoepfer AM, Trummler M, Seeholzer P, Seibold-Schmid B, Seibold F: Discriminating IBD from IBS: comparison of the test performance of fecal markers, blood leukocytes, CRP, and IBD antibodies. Inflamm Bowel Dis 2008, 14(1):32-39.

14. Hanevik K, Hausken T, Morken MH, Strand EA, Morch K, Coll P, Helgeland L, Langeland N: Persisting symptoms and duodenal inflammation related to Giardia duodenalis infection. J Infect 2007, 55(6):524-530.

15. Damms A, Bischoff SC: Validation and clinical significance of a new calprotectin rapid test for the diagnosis of gastrointestinal diseases. Int J Colorectal Dis 2008, 23(10):985-992

16. Berni Canani R, Rapacciuolo L, Romano MT, Tanturri de Horatio L, Terrin G, Manguso F, Cirillo P, Paparo F, Troncone R: Diagnostic value of faecal calprotectin in paediatric gastroenterology clinical practice. Dig Liver Dis 2004, 36(7):467-470.

17. Roseth AG, Kristinsson J, Fagerhol MK, Schjonsby H, Aadland E, Nygaard K Roald B: Faecal calprotectin: a novel test for the diagnosis of colorectal cancer? Scand J Gastroenterol 1993, 28(12):1073-1076.

18. Tibble JA, Sigthorsson G, Foster R, Scott D, Fagerhol MK, Roseth A Bjarnason I: High prevalence of NSAID enteropathy as shown by a simple faecal test. Gut 1999, 45(3):362-366.

19. Savino F, Castagno E, Calabrese R, Viola S, Oggero R, Miniero R: High Faecal Calprotectin Levels in Healthy, Exclusively Breast-Fed Infants. Neonatology 2009, 97(4):299-304.

20. Josefsson S, Bunn SK, Domellof M: Fecal calprotectin in very low birth weight infants. J Pediatr Gastroenterol Nutr 2007, 44(4):407-413.

21. Yang Q, Smith PB, Goldberg RN, Cotten CM: Dynamic change of fecal calprotectin in very low birth weight infants during the first month of life. Neonatology 2008, 94(4):267-271.

22. Fagerberg UL, Loof L, Merzoug RD, Hansson LO, Finkel Y: Fecal calprotectin levels in healthy children studied with an improved assay. J Pediatr Gastroenterol Nutr 2003, 37(4):468-472.

23. Betson M, Sousa-Figueiredo JC, Rowell C, Kabatereine NB, Stothard JR: Intestinal schistosomiasis in mothers and young children in Uganda: investigation of field-applicable markers of bowel morbidity. Am J Trop Med Hyg 2010, 83(5):1048-1055

24. Hestvik E, Tylleskar T, Kaddu-Mulindwa DH, Ndeezi G, Grahnquist L, Olafsdottir E, Tumwine JK: Helicobacter pylori in apparently healthy children aged 0-12 years in urban Kampala, Uganda: a communitybased cross sectional survey. BMC Gastroenterol 2010, 10(1):62

25. Asilsoy S, Babayigit A, Olmez D, Uzuner N, Karaman O, Oren O, Turgut CS, Tezcan D: Helicobacter Pylori Infection and Gastroesophageal Reflux in Asthmatic Children. J Trop Pediatr 2007.
26. Bremner A, Roked S, Robinson R, Phillips I, Beattie M: Faecal calprotectin in children with chronic gastrointestinal symptoms. Acta Paediatr 2005, 94(12):1855-1858.

27. Nissen AC, van Gils CE, Menheere PP, Van den Neucker AM, van der Hoeven MA, Forget PP: Fecal calprotectin in healthy term and preterm infants. J Pediatr Gastroenterol Nutr 2004, 38(1):107-108

28. Pezzilli R, Barassi A, Morselli Labate AM, Finazzi S, Fantini L, Gizzi G, Lotzniker M, Villani V, Melzi d'Eril G, Corinaldesi R: Fecal calprotectin levels in patients with colonic polyposis. Dig Dis Sci 2008, 53(1):47-51.

29. Hiatt RA, Markell EK, Ng E: How many stool examinations are necessary to detect pathogenic intestinal protozoa? Am J Trop Med Hyg 1995, 53(1):36-39.

30. Goka AK, Rolston DD, Mathan VI, Farthing MJ: The relative merits of faecal and duodenal juice microscopy in the diagnosis of giardiasis. Trans $R$ Soc Trop Med Hyg 1990, 84(1):66-67.

31. Ortega YR, Adam RD: Giardia: overview and update. Clin Infect Dis 1997. 25(3):545-549, quiz 550

32. Go MF: Review article: natural history and epidemiology of Helicobacter pylori infection. Aliment Pharmacol Ther 2002, 16(Suppl 1):3-15.

33. Herrera V, Parsonnet J: Helicobacter pylori and gastric adenocarcinoma. Clin Microbiol Infect 2009, 15(11):971-976.

34. Summerton CB, Longlands MG, Wiener K, Shreeve DR: Faecal calprotectin: a marker of inflammation throughout the intestinal tract. Eur $J$ Gastroenterol Hepatol 2002, 14(8):841-845.

35. Tibble JA, Sigthorsson G, Foster R, Forgacs I, Bjarnason I: Use of surrogate markers of inflammation and Rome criteria to distinguish organic from nonorganic intestinal disease. Gastroenterology 2002, 123(2):450-460.

36. Thia KT, Loftus EV Jr, Sandborn WJ, Yang SK: An update on the epidemiology of inflammatory bowel disease in Asia. Am J Gastroenterol 2008, 103(12):3167-3182

37. von Roon AC, Karamountzos L, Purkayastha S, Reese GE, Darzi AW, Teare JP, Paraskeva P, Tekkis PP: Diagnostic precision of fecal calprotectin for inflammatory bowel disease and colorectal malignancy. Am J Gastroenterol 2007, 102(4):803-813.

38. Konikoff MR, Denson LA: Role of fecal calprotectin as a biomarker of intestinal inflammation in inflammatory bowel disease. Inflamm Bowel Dis 2006, 12(6):524-534.

39. Campeotto F, Butel MJ, Kalach N, Derrieux S, Aubert-Jacquin C, Barbot L, Francoual C, Dupont C, Kapel N: High faecal calprotectin concentrations in newborn infants. Arch Dis Child Fetal Neonatal Ed 2004, 89(4):F353-355.

40. Dorosko SM, Mackenzie T, Connor Rl: Fecal calprotectin concentrations are higher in exclusively breastfed infants compared to those who are mixed-fed. Breastfeed Med 2008, 3(2):117-119.

\section{Pre-publication history}

The pre-publication history for this paper can be accessed here: http://www.biomedcentral.com/1471-2431/11/9/prepub

\section{doi:10.1186/1471-2431-11-9}

Cite this article as: Hestvik et al:: Faecal calprotectin concentrations in apparently healthy children aged 0-12 years in urban Kampala, Uganda: a community-based survey. BMC Pediatrics 2011 11:9.

\section{Submit your next manuscript to BioMed Central and take full advantage of:}

- Convenient online submission

- Thorough peer review

- No space constraints or color figure charges

- Immediate publication on acceptance

- Inclusion in PubMed, CAS, Scopus and Google Scholar

- Research which is freely available for redistribution 